\title{
Karakteristik Pengeringan Jamur Tiram (Pleurotus ostreatus var. florida) Menggunakan Pengering Tipe Fluidized Bed Drier
}

\author{
Drying Characteristic of Oyster Mushroom (Pleurotus ostreatus var. florida) in A Fluidized Bed Drier \\ Tjahja Muhandri ${ }^{1,2 *}$, Sarah Diana Yulianti ${ }^{1}$, Elis Nina Herliyana ${ }^{3}$ \\ ${ }^{1}$ Departemen Ilmu dan Teknologi Pangan, Institut Pertanian Bogor, Kampus IPB Darmaga, \\ PO BOX 220 Bogor 16002, Indonesia \\ ${ }^{2}$ Seafast Center, Institut Pertanian Bogor, Jl. Ulin No. 1 Gedung SEAFAST Center, \\ Kampus IPB Darmaga, Bogor 16680, Indonesia \\ ${ }^{3}$ Departemen Silvikultur, Institut Pertanian Bogor, Jl. Lingkar Akademik Kampus IPB Darmaga, Bogor 16680, Indonesia \\ Email: cahyomuhandri@yahoo.com
}

Submisi: 4 April 2016; Penerimaan: 28 September 2017

\begin{abstract}
ABSTRAK
Proses pengeringan jamur tiram (Pleurotus ostreatus) dilakukan untuk meningkatkan mutu dari jamur tiram dan mempermudah penanganannya. Penurunan mutu yang terjadi ketika jamur tiram dikeringkan adalah warna jamur yang coklat gelap dan tidak disukai konsumen. Kondisi ini terjadi karena penanganan sebelum pengeringan yang tidak tepat serta proses pengeringan yang terlalu lama. Penelitian ini dilakukan untuk mengetahui persamaan laju pengeringan jamur tiram, prediksi waktu pengeringan dan perilaku rehidrasinya. Jamur tiram diberi enam perlakuan yang berbeda yaitu (1) kontrol, (2) dicuci air bersih, (3) blansir, (4) blansir yang dilanjutkan dengan perendaman dalam natrium metabisulfit, (5) blansir dalam larutan natrium metabisulfit, dan (6) perendaman dalam larutan natrium metabisulfit yang dilanjutkan dengan blansir. Pengeringan dilakukan dengan fluidized bed dryer pada suhu $60{ }^{\circ} \mathrm{C}$ dan kecepatan udara pengering yang berada pada kisaran $0,619 \mathrm{~m} /$ detik hingga $0,839 \mathrm{~m} /$ detik sampai sampel mencapai kadar air kesetimbangan. Kadar air kesetimbangan (moisture equilibrium) dicapai setelah pengeringan selama 270 - 330 menit. Hasil pengujian menunjukkan bahwa model Lewis lebih sesuai dibandingkan dengan model Page untuk memprediksi laju pengeringan jamur tiram. Sampel jamur tiram tanpa perlakuan dan jamur tiram dengan perlakuan pencucian tanpa blansir merupakan sampel terbaik dengan waktu untuk mengeringkan hingga mencapai kadar air $12 \%$ adalah 150 menit dan rasio rehidrasi yang lebih tinggi dibandingkan sampel lainnya.
\end{abstract}

Kata kunci: Laju pengeringan; pre-treatment; jamur tiram; rehidrasi

\begin{abstract}
The current practice for improving the quality and for ease handling of the oyster mushroom is drying. The drawback of this process results in dark color of the mushroom once it is dried. This color quality reduction wascaused by an unappropriate handling before drying and an over process of the drying. Thus, the objective of the research was to determine the most suitable model for drying rate of the mushroom and the best pre-treatments before drying. In this research, the influence of six pre-treatments before drying (1) control/without any pre-treatment, (2) washed using water, (3) blanching, (4) blanching followed by immersion in sodium metabisulphite solution, (5) blanching using a sodium metabisulphite solution, and (6) soaking in sodium metabisulphite solution, followed by blanching, on the quality of the mushroom (rehydration behavior) was elucidated. Those six samples were subjected to drying process using fluidized bed drier at $60^{\circ} \mathrm{C}$ with airflow rate between 0.619 and $0.839 \mathrm{~m} / \mathrm{s}$ until the samples reached equilibrium
\end{abstract}


moisture content. The equilibrium moisture content was achieved after drying process of the mushroom from 270 to 330 minutes. Results indicated that Lewis model more suitable than Page model for prediction of the mushroom drying rate. Results also showed that the control/without any pre-treatment before drying and sample with washed using water were the best pre-treatments before drying resulted in the highest rehydration ratio with the short time of 150 minutes to reach the moisture content of $12 \%$.

Keywords: Drying rate; pretreatment; oyster mushroom; rehydration

\section{PENDAHULUAN}

Jamur tiram (Pleurotus ostreatus) merupakan salah satu jenis edible fungi yang cukup digemari karena rasanya yang lezat dan teksturnya yang kenyal. Menurut penelitian yang telah dilakukan Patil dkk. (2010), jamur tiram mengandung 19 jenis asam amino, selain sistein, dan cukup kaya kandungan asam glutamat, asam aspartat, dan lisin. Kandungan vitamin $\mathrm{C}$ dan asam folat juga ditemukan dalam jamur tiram. Mineral kalsium dan besi merupakan jenis mineral yang terkandung cukup tinggi dalam jamur tiram. Kadar antioksidan ergothionin juga ditemukan dalam jumlah yang cukup tinggi, yakni $1,73 \mathrm{mg} / \mathrm{g}$ pada jamur tiram, lebih tinggi dibandingkan dengan jenis jamur lainnya (Bhattacharya dkk., 2014). Alam dkk. (2008) menambahkan, kandungan protein dalam jamur tiram sekitar 20-25\%, serat 37-48\% (bk), lemak 4-5\%, karbohidrat $37-48 \%$, mineral $8-13 \%$, dan kadar air sebanyak $86-87,5 \%$.

Kadar air dan nutrisi yang cukup tinggi membuat jamur tiram memiliki potensi mengalami kerusakan secara biologis maupun fisik. Struktur tubuhnya saat berbuah yang rapuh dan umur simpan yang pendek karena penyimpangan fisik yang cepat terjadi setelah pemanenan, seperti berair, lunak, pencoklatan, berbau tak sedap, menjadi kendala utama pemasaran jamur tiram. Kondisi ini memerlukan proses pengawetan, terutama pengeringan.

Berbagai penelitian pengeringan jamur telah dilakukan diantaranya adalah pengeringan jamur tiram menggunakan microwave (Bhattacharya dkk., 2014), kinetika pengeringan dan karakteristik rehidrasi jamur kancing menggunakan microwave oven (Giri dan Prasat, 2007), pengaruh pengeringan beku terhadap tekstur jamur kancing (Guiné dan Barroca, 2011), serta kinetika pengeringan dan karakteristik rehidrasi jamur kancing menggunakan pengering kabinet (Doymaz, 2014).

Pengeringan dipilih sebagai metode yang digunakan untuk mengawetkan jamur tiram karena prosesnya yang relatif mudah diaplikasikan pada berbagai skala industri jamur tiram. Pengeringan dapat dilakukan secara konvensional dengan bantuan sinar matahari dan dapat pula dilakukan menggunakan alat pengering (pengering kabinet, microwave, oven dan fluidized bed drier). Walde dkk. (2006) yang menyatakan bahwa fluidized bed drier memiliki kelebihan dalam mempercepat waktu pengeringan dan menghasilkan kualitas produk lebih baik dibandingkan alat pengering lain, seperti vacuum dryer dan cabinet drier.

Pretreatment dilakukan sebagai usaha untuk meningkatkan efektivitas pengeringan, meningkatkan penampakan dan meningkatkan preferensi konsumen. Pretreatment terhadap jamur yang akan dikeringkan diantaranya adalah perendaman dalam larutan asam sitrat $(0,5 \%)$ pada suhu $20{ }^{\circ} \mathrm{C}$ selama 3 menit (Doymaz 2014), blanching dan blanching yang dilanjutkan dengan perendaman dalam larutan Natrium Metabisulfit (Walde dkk., 2006) dan ultrasonifikasi (Jambrak dkk., 2007).

Efektivitas pengeringan dapat ditingkatkan dengan keakuratan prediksi waktu pengeringan menggunakan persamaan laju pengeringan. Model persamaan laju pengeringan yang digunakan adalah model Lewis dan model Page. Model Lewis dan model Page digunakan karena cukup sederhana untuk diterapkan (Erbay dan Icier, 2010). Penelitian ini bertujuan untuk mengidentifikasi model persamaan laju pengeringan yang sesuai untuk jamur tiram, prediksi waktu yang dibutuhkan untuk pengeringan dan perilaku rehidrasi jamur tiram kering.

\section{METODE PENELITIAN}

\section{Bahan}

Bahan utama yang digunakan dalam penelitian ini adalah jamur tiram (dari Laboratorium Departemen Silvikultur, Fakultas Kehutanan, IPB, Bogor).

\section{Pretreatment Jamur Tiram}

Proses perlakuan pada jamur yang dilakukan sebelum pengeringan (pretreatment), diadaptasi dari metode pretreatment yang dilakukan oleh Walde dkk. (2006). Jamur tiram segar sebanyak 18 tudung, umur panen 3 hari dengan bobot 4,0-6,0 g dibersihkan dari kotoran fisik dan dibagi menjadi enam sampel untuk diberikan perlakuan yang berbeda. 
Tabel 1. Variabel perlakuan sampel

\begin{tabular}{lc}
\hline \multicolumn{1}{c}{ Kondisi pretreatment } & Kode \\
\hline Tanpa pretreatment & JS \\
Pencucian tanpa b̈lanching & JC \\
Blanching (air dengan suhu $90{ }^{\circ} \mathrm{C}$ selama 2 menit) & JB \\
Blanching dilanjutkan perendaman $\mathrm{Na}_{2} \mathrm{~S}_{2} \mathrm{O}_{5} 2000$ ppm (6 menit) & $\mathrm{JMa}$ \\
Blanching dengan larutan $\mathrm{Na}_{2} \mathrm{~S}_{2} \mathrm{O}_{5} 2000 \mathrm{ppm}$ & $\mathrm{JMb}$ \\
Perendaman $\mathrm{Na}_{2} \mathrm{~S}_{2} \mathrm{O}_{5} 2000$ ppm dilanjutkan dengan blanching & $\mathrm{JMc}$ \\
\hline
\end{tabular}

Sampel pertama tidak diberikan perlakuan, sampel kedua dicuci dengan aqudes, sampel ketiga di-blanching, sampel keempat di-blanching kemudian direndam dalam natrium metabisulfit (Sigma, USA) $2.000 \mathrm{ppm}$ selama 15 menit, sampel kelima di-blanching dalam larutan natrium metabisulfit 2.000 ppm selama 6 menit, sedangkan sampel keenam direndam dalam larutan natrium metabisulfit 2.000 ppm selama 6 menit kemudian di-blanching. Variabel perlakuan terhadap sampel dapat dilihat dalam Tabel 1 . Penelitian dilakukan sebanyak 2 ulangan.

Blanching pada penelitian ini dilakukan dengan menggunakan air yang dipanaskan terlebih dahulu hingga mencapai suhu sekitar $90{ }^{\circ} \mathrm{C}$, kemudian bahan dimasukkan ke dalam air panas dan didiamkan selama 2 menit. Setelah blanching, jamur tiram ditiriskan dan disusun di kawat kasa dan diletakkan di atas nampan berlubang untuk dikeringkan.

\section{Pengeringan Jamur Tiram}

Metode pengeringan yang dilakukan diadaptasi dari metode yang dilakukan oleh Kotwaliwale dkk. (2007). Pada penelitian ini pengeringan dilakukan dengan menggunakan alat pengering tipe fluidized bed drier yang dikembangkan oleh Seafast Center - IPB. Alat memiliki dimensi panjang 120 $\mathrm{cm}$, lebar $92 \mathrm{~cm}$, dan tinggi $150 \mathrm{~cm}$, serta memiliki kapasitas sekitar 1,5-2,0 kg jamur tiram segar. Fluidized bed dyer yang digunakan memiliki satu lapis tray dengan luasan $110 \mathrm{~cm}$ $\times 65 \mathrm{~cm}$. Alat pengering ini bekerja dengan menggunakan panas dari kompor gas dan udara panas ditarik oleh kipas angin kemudian dihembuskan ke nampan berlubang tempat jamur dikeringkan (Gambar 1).

Jamur tiram ditimbang setiap 5 menit sekali pada 30 menit pertama, 10 menit sekali pada 90 menit selanjutnya, dan 30 menit sekali hingga mencapai moisture equilibrium, yakni ketika bobot jamur tiram tidak lagi mengalami

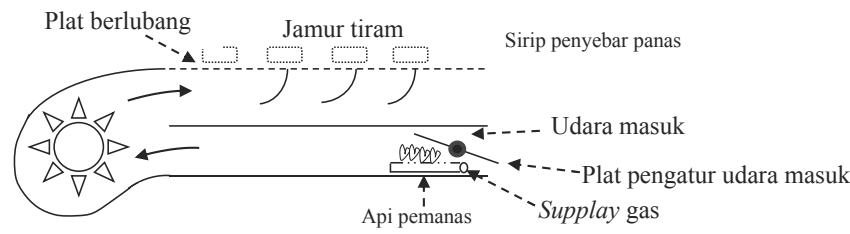

Gambar 1. Skema alat pengering yang digunakan dalam penelitian perubahan. Suhu pengeringan $60 \pm 2{ }^{\circ} \mathrm{C}$ dan kecepatan angin $0,639 \mathrm{~m} /$ detik hingga $0,839 \mathrm{~m} /$ detik (penelitian pendahuluan menggunakan anemometer Ogawa Seiki, Jepang). Kecepatan angin tidak menyebabkan jamur berterbangan sehingga penimbangan dilakukan dengan cara kasa tempat menaruh jamur, diangkat dan dikeluarkan dari pengering untuk ditimbang (ketelitian timbangan 0,001 g).

\section{Analisis Kadar Air Metode Oven (AOAC, 1995)}

Cawan alumunium dikeringkan dalam oven selama 15 menit, didinginkan dalam desikator selama 15 menit, kemudian ditimbang (A). Sejumlah sampel B (sekitar $5 \mathrm{~g}$ ) dimasukkan ke dalam cawan yang telah diketahui beratnya. Cawan beserta isi dikeringkan di dalam oven bersuhu 105 ${ }^{\circ} \mathrm{C} \pm 1{ }^{\circ} \mathrm{C}$ selama 5 jam (berat konstan), didinginkan dalam desikator, dan ditimbang (C). Perhitungan kadar air dilakukan dengan menggunakan rumus:

$$
\begin{aligned}
& \text { Kadar air }(\% \mathrm{bb})=\frac{\mathrm{B}-(\mathrm{C}-\mathrm{A})}{\mathrm{B}} \times 100 \% \\
& \text { Kadar air }(\% \mathrm{bk})=\frac{\mathrm{B}-(\mathrm{C}-\mathrm{A})}{\mathrm{C}-\mathrm{A}} \times 100 \%
\end{aligned}
$$

\section{Pembuatan persamaan model laju pengeringan metode Lewis dan metode Page}

Persamaan laju pengeringan memiliki banyak model, seperti model Persamaan model Lewis dan model Page dapat dibuat menggunakan data kadar air kesetimbangan, kadar air inisiasi, dan kadar air pada waktu t. Persamaan model Lewis didapatkan dengan cara memplotkan variabel waktu pada sumbu x dan variabel ln MR pada sumbu y. Nilai konstanta laju pengeringan dari persamaan ini diambil dari nilai slope yang dihasilkan. Persamaan model Page didapatkan dengan cara memplotkan variabel $\ln (\mathrm{t})$ pada sumbu $\mathrm{x}$ dan variabel $\ln (-\ln \mathrm{MR})$ pada sumbu y. Nilai konstanta pengeringan dari persamaan ini diambil dari eksponensial intercept, sedangkan nilai koefisien $\mathrm{n}$ diambil dari nilai slope-nya.

Laju pengeringan dapat dihitung berdasarkan penurunan kadar air terhadap waktu. Perhitungan yang lebih presisi dapat dilakukan dengan membuat pendekatan persamaan model laju pengeringan. Persamaan laju pengeringan yang diaplikasikan pada penelitian ini mengikuti model Lewis dan Page (Erbay dan Icier, 2010). Model Lewis mengasumsikan bahwa perubahan kadar air bahan pada periode laju menurun (falling rate) adalah proposional terhadap perbedaan antara kadar air dan kadar air kesetimbangan (moisture equilibrium).

$$
\mathrm{MR}=\frac{\mathrm{M}_{\mathrm{t}}-\mathrm{M}_{\mathrm{e}}}{\mathrm{M}_{\mathrm{i}}-\mathrm{M}_{\mathrm{e}}}=\exp (-\mathrm{kt})
$$


Dengan adalah kadar air (basis kering) pada berbagai waktu t; adalah kadar air kesetimbangan; adalah kadar air awal dari bahan; dan $\mathrm{k}$ adalah konstanta pengeringan. disebut juga sebagai moisture content ratio atau MR.

Model Page merupakan modifikasi dari model Lewis (Model Lewis merupakan model Page dengan $n=1$ ) dengan tujuan untuk mendapatkan model yang lebih presisi.

$\mathrm{MR}=\frac{\mathrm{M}_{\mathrm{t}}-\mathrm{M}_{\mathrm{e}}}{\mathrm{M}_{\mathrm{i}}-\mathrm{M}_{\mathrm{e}}}=\exp \left(-\mathrm{kt}^{\mathrm{n}}\right)$

\section{Penentuan Rasio Rehidrasi}

Rehidrasi merupakan proses penyerapan air kembali setelah bahan melalui proses penghilangan air. Rasio rehidrasi (RR) merupakan selisih kadar air produk pada waktu $\mathrm{t}$ tehadap kadar air awal. Rasio rehidrasi diperlihatkan dalam persamaan 5 , dengan $\mathrm{W}_{2}$, dan $\mathrm{W}_{1}$ berturut-turut adalah bobot produk setelah waktu t rehidrasi dan bobot kering bahan (Doymaz, 2014). Data hasil kapasitas rehidrasi dan rasio rehidrasi kemudian diplotkan dalam kurva perbandingan kapasitas rehidrasi jamur tiram terhadap waktu dan kurva perbandingan rasio rehidrasi jamur tiram terhadap waktu.

$\mathrm{RR}=\frac{W_{2}}{W_{1}}$

\section{HASIL DAN PEMBAHASAN}

\section{Penurunan Kadar Air}

Jamur tiram yang telah mengalami pretreatment disajikan pada Gambar 1. Pengaruh kondisi pretreatment yang berbeda terhadap penurunan kadar air ditunjukkan dalam bentuk kurva penurunan kadar air (Gambar 2). Secara umum, penurunan kadar air berlangsung dengan cepat pada 100 menit pertama, ditunjukkan dengan kurva yang curam, kemudian melambat dan kadar air cenderung konstan mulai pada menit ke 200. Standar Codex (1981) menyebutkan bahwa kadar air jamur kering dikatakan aman jika kadar air lebih rendah dari $12 \%(\mathrm{bb})$.

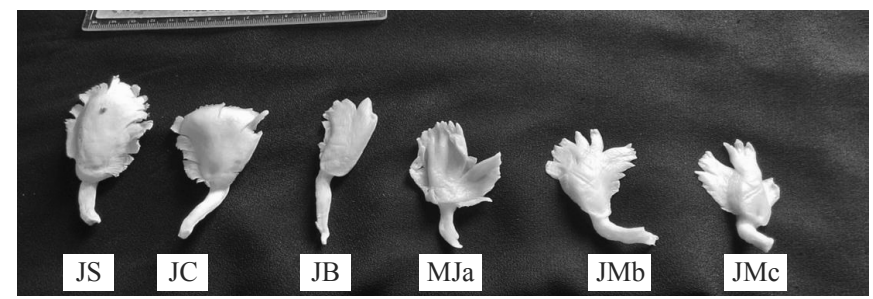

Gambar 1. Hasil pretreatment jamur tiram. Kiri ke kanan, JS (Tanpa pretreatment), JC (Pencucian tanpa blansir), JB (Blansir (dalam air bersuhu $90{ }^{\circ} \mathrm{C}$ selama 2 menit)), JMa (Blansir dilanjutkan perendaman $\mathrm{Na}_{2} \mathrm{~S}_{2} \mathrm{O}_{5} 2.000$ ppm selama 6 menit), JMb (Blansir dengan larutan $\mathrm{Na}_{2} \mathrm{~S}_{2} \mathrm{O}_{5} 2000 \mathrm{ppm}$ ), JMc (Perendaman $\mathrm{Na}_{2} \mathrm{~S}_{2} \mathrm{O}_{5}$ 2.000 ppm dilanjutkan dengan blansir).

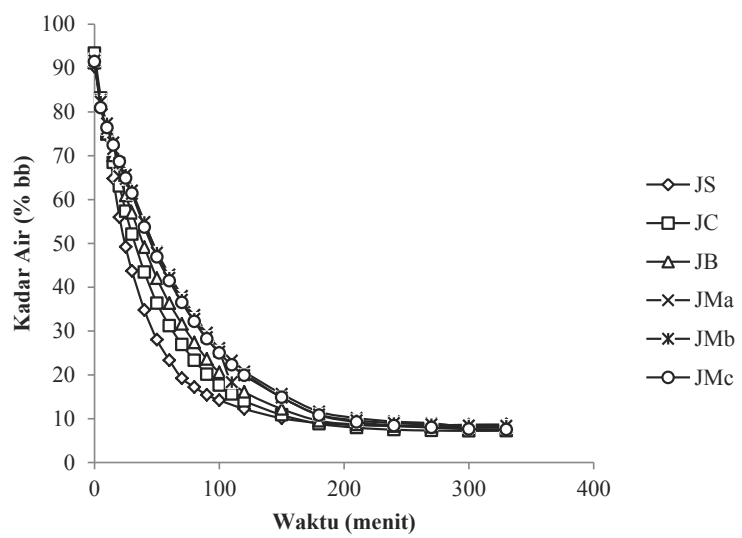

Gambar 2. Kurva penurunan kadar air basis basah pada enam kondisi pretreatment

Gambar 2 menunjukkan bahwa penurunan kadar air paling cepat terjadi pada sampel yang tidak diberikan perlakuan (JS), kemudian secara berturut-turut diikuti oleh sampel JC, JB, JMc, JMb, dan JMa. Sampel JS dan JC dapat mencapai kadar air di bawah $12 \%$ (bb) pada menit ke-150, sedangkan waktu yang dibutuhkan sampel lain sekitar 180 menit. Waktu pengeringan ini jauh lebih cepat dibandingkan dengan pengeringan menggunakan pengering tipe kabinet, yang membutuhkan waktu 8 - 12 jam (Arora dkk., 2011) pada jumlah sampel yang sama, sedangkan $\mathrm{RH}$ udara pengering, RH lingkungan, dan volumetric flow rate diabaikan. Kadar air kesetimbangan (moisture equilibrium) diperoleh pada pengeringan selama 270-330 menit, tergantung sampel jamur tiram (Tabel 3).

Perbedaan waktu dan laju penurunan kadar air sampel yang berbeda disebabkan oleh perbedaan kadar air awal sampel dan perubahan sifat fisik sampel saat diberikan pretreatment. Pretreatment pencucian menyebabkan peningkatan kadar air awal sampel sebesar 3,08\% (bb) dan merupakan yang paling tinggi dibandingkan dengan peningkatan kadar air awal sampel yang diberi pretreatment blansir sebesar 0,92-1,66\% (bb) dan lebih tinggi dari kadar air awal jamur tiram segar. Kadar air awal dan kadar air setimbang (moisture equilibrium) sampel jamur tiram dapat dilihat pada Tabel 2.

Tabel 2. Kadar air jamur tiram sebelum dan sesudah pengeringan

\begin{tabular}{crrrr}
\hline \multirow{2}{*}{ Perlakuan } & \multicolumn{2}{c}{ Kadar air awal } & \multicolumn{2}{c}{$\begin{array}{c}\text { Kadar air kesetimbangan } \\
\text { (Moisture equilibrium })\end{array}$} \\
\cline { 2 - 5 } & \multicolumn{1}{c}{$(\% \mathrm{bb})$} & \multicolumn{1}{c}{$(\% \mathrm{bk})$} & \multicolumn{1}{c}{$(\% \mathrm{bb})$} & \multicolumn{1}{c}{$(\% \mathrm{bk})$} \\
\hline JS & $90,32 \pm 0,42$ & $938,98 \pm 42,47$ & $8,44 \pm 0,27$ & $87,77 \pm 2,84$ \\
JC & $93,40 \pm 1,00$ & $1435,28 \pm 230,44$ & $7,30 \pm 0,73$ & $112,24 \pm 11,25$ \\
JB & $91,24 \pm 0,29$ & $1044,02 \pm 39,23$ & $8,05 \pm 1,03$ & $92,13 \pm 12,79$ \\
JMa & $91,98 \pm 0,06$ & $1155,64 \pm 7,44$ & $8,06 \pm 0,02$ & $101,30 \pm 0,27$ \\
JMb & $91,70 \pm 0,36$ & $1110,90 \pm 57,18$ & $8,42 \pm 0,54$ & $102,10 \pm 6,66$ \\
JMc & $91,46 \pm 0,49$ & $1076,95 \pm 67,93$ & $7,61 \pm 0,34$ & $89,80 \pm 3,96$ \\
\hline
\end{tabular}




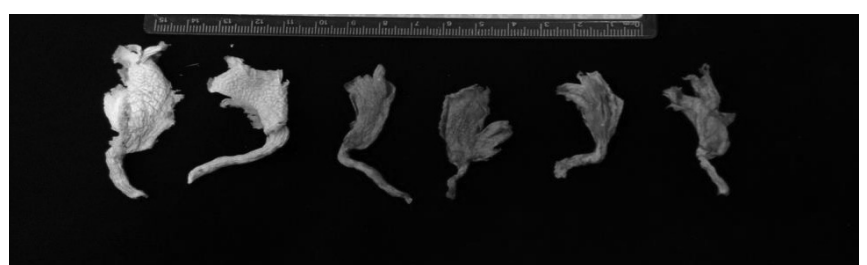

Gambar 3. Jamur tiram setelah dikeringkan selama 240 menit. Kiri ke kanan, JS (Tanpa pretreatment), JC (Pencucian tanpa blansir), $\mathrm{JB}$ (Blansir (dalam air bersuhu $90{ }^{\circ} \mathrm{C}$ selama 2 menit)), JMa (Blansir dilanjutkan perendaman $\mathrm{Na}_{2} \mathrm{~S}_{2} \mathrm{O}_{5} 2.000$ ppm selama 6 menit), JMb (Blansir dengan larutan $\mathrm{Na}_{2} \mathrm{~S}_{2} \mathrm{O}_{5} 2.000$ ppm), JMc (Perendaman $\mathrm{Na}_{2} \mathrm{~S}_{2} \mathrm{O}_{5} 2.000$ ppm dilanjutkan dengan blansir).

Kadar air kesetimbangan (moisture equilibrium) yang dicapai pada penelitian ini adalah 7,25\% (bb) hingga 8,68\% (bb), lebih rendah dibandingkan dengan hasil penelitian yang dilakukan oleh Bhattacharya dkk. (2014) tentang pengeringan jamur tiram menggunakan microwave pada suhu $69{ }^{\circ} \mathrm{C}$ yang mencapai 9\% (bb) dan penelitian Kulshrestha dkk. (2009) yang mencapai 10\% (bk). Kisaran kadar air kesetimbangan yang dicapai pada penelitian ini dapat mencapai kadar air akhir tertinggi jamur tiram yang dikeringkan menggunakan freeze dyier (model Table Top TFD5505, Uniequip, Germany) yakni 8,55\% (bb), tetapi tidak dapat mencapai kadar air akhir terendahnya, yakni 5,26\% (bb) (Guiné dan Barroca, 2011).

Pretreatment blansir yang diberikan pada sampel JB, $\mathrm{JMa}, \mathrm{JMb}$, dan JMc menghasilkan data penurunan kadar air yang lebih lambat dibandingkan sampel yang hanya diberikan pretreatment pencucian dan sampel yang tidak diberikan pretreatment. Hasil pada penelitian ini juga sesuai dengan penelitian yang dilakukan oleh Hassan dan Medany (2014), yakni sampel kontrol menunjukkan waktu pengeringan yang paling singkat, sedangkan pretreatment blanching memperpanjang waktu pengeringan dibandingkan dengan kontrol.

Penurunan kadar air yang lebih lambat pada empat sampel yang diberikan pretreatment blansir tersebut dapat dijelaskan dengan mekanisme penyusutan volum jamur tiram. Pelipatan lamella dan pengeluaran udara di antara lamella pada jaringan jamur terjadi selama blanching, sehingga terjadi penyusutan volumetrik. Jaringan pada jamur kemudian disalut oleh air yang menggantikan udara yang keluar, dan densitas jamur tiram meningkat (Vullioud dkk., 2011).

Natrium metabisulfit merupakan salah satu bahan tambahan pangan yang multifungsi. Natrium metabisulfit dapat digunakan sebagai pengawet pangan, bahan penolong, pencegah terjadinya pencoklatan enzimatik dan non enzimatik, dan dapat pula sebagai bleaching agent (Belloso dan Fortuny, 2010). Natrium metabisulfit digunakan dalam penelitian ini sebagai pencegah terjadinya reaksi pencoklatan enzimatik pada jamur tiram.Menurut Food and Drugs Association (FDA), batas maksimum penggunaan senyawa yang merupakan turunan dari bahan sulfida ini adalah sebanyak 2.000-3.000 ppm.

Penelitian yang dilakukan oleh Arora dkk. (2011) menunjukkan bahwa perendaman dalam larutan natrium metabisulfit sebanyak 2.500 ppm selama 15 menit menghasilkan nilai optical density (OD) yang paling rendah. Nilai OD mengekspresikan nilai indeks pencoklatan. Pada produk jamur kering, semakin rendah nilai OD yang dihasilkan, mutu jamur dianggap semakin baik. Hasil pengeringan pada menit ke-240 disajikan pada Gambar 3.

\section{Model Persamaan Laju Pengeringan Jamur Tiram}

Persamaan laju pengeringan memiliki banyak model, seperti model Page, Henderson dan Pabis, Lewis, Logaritmik, Verma dan Midili (Ghaderi dkk., 2012). Model persamaan laju pengeringan jamur tiram dibuat menggunakan model yang paling sederhana, yakni model Lewis dan model Page. Kedua model dievaluasi untuk kemudian ditentukan model persamaan laju pengeringan yang terbaik, yakni yang paling dapat merepresentasikan kondisi jamur tiram selama pengeringan.

Hasil pemetaan data laju pengeringan jamur tiram seluruh perlakuan dapat dilihat dalam Gambar 4 untuk model Lewis dan Gambar 5 untuk Model Page. Secara umum, terlihat bahwa kurva yang dihasilkan dari model Lewis lebih terdiferensiasi dibandingkan dengan kurva yang dihasilkan dari model Page. Perbedaan kedua model tersebut ditunjukkan oleh perbedaan nilai $\mathrm{R}^{2}$ yang dihasilkan. Tabel 3 menunjukkan data yang lebih rinci, persamaan-persamaan pada model

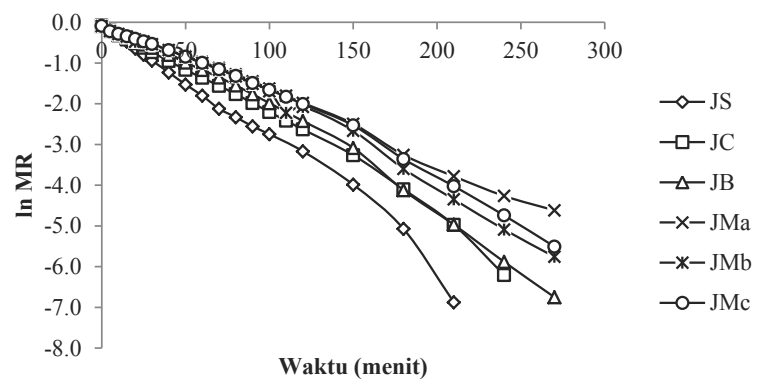

Gambar 4. Kurva pengeringan semua perlakuan menggunakan model Lewis

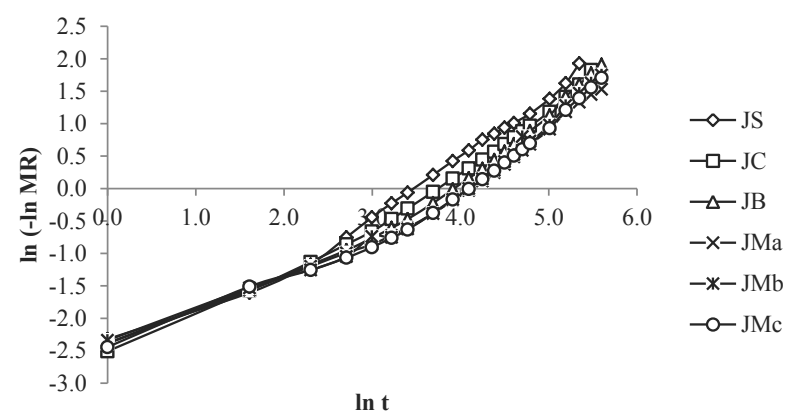

Gambar 5. Kurva pengeringan semua perlakuan menggunakan model Page 
Tabel 3. Model persamaan laju pengeringan berdasarkan model Lewis dan model Page pada semua perlakuan

\begin{tabular}{cccclc}
\hline \multirow{2}{*}{$\begin{array}{c}\text { Perla- } \\
\text { kuan }\end{array}$} & $\begin{array}{c}\text { Waktu } \\
\text { Equilibrium } \\
\text { (menit) }\end{array}$ & $\begin{array}{c}\text { Persamaan Laju } \\
\text { Pengeringan }\end{array}$ & $\mathrm{R}^{2}$ & Persamaan Laju Pengeringan & $\mathrm{R}^{2}$ \\
\hline JS & 240 & $\mathrm{MR}=\exp (-0,0293 \mathrm{t})$ & 0,98 & $\mathrm{MR}=\exp \left(-0,0610 \mathrm{t}^{0,8278}\right)$ & 0,98 \\
$\mathrm{JC}$ & 240 & $\mathrm{MR}=\exp (-0,0237 \mathrm{t})$ & 0,99 & $\mathrm{MR}=\exp \left(-36,9808 \mathrm{t}^{1,2195}\right)$ & 0,98 \\
$\mathrm{JB}$ & 300 & $\mathrm{MR}=\exp (-0,0241 \mathrm{t})$ & 0,99 & $\mathrm{MR}=\exp \left(-0,0522 \mathrm{t}^{0,8016}\right)$ & 0,96 \\
$\mathrm{JMa}$ & 300 & $\mathrm{MR}=\exp (-0,0172 \mathrm{t})$ & 0,99 & $\mathrm{MR}=\exp \left(-17,7077 \mathrm{t}^{0,7375}\right)$ & 0,96 \\
$\mathrm{JMb}$ & 300 & $\mathrm{MR}=\exp (-0,0207 \mathrm{t})$ & 0,99 & $\mathrm{MR}=\exp \left(-0,0533 \mathrm{t}^{0,7673}\right)$ & 0,95 \\
$\mathrm{JMc}$ & 300 & $\mathrm{MR}=\exp (-0,0194 \mathrm{t})$ & 0,99 & $\mathrm{MR}=\exp \left(-0,0517 \mathrm{t}^{\mathrm{0}, 7641}\right)$ & 0,95 \\
\hline
\end{tabular}

Lewis memiliki nilai $\mathrm{R}^{2}$ yang lebih tinggi dibandingkan nilai $\mathrm{R}^{2}$ pada persamaan-persamaan model Page.

Validasi model tidak dilakukan pada penelitian ini. Hasil perbandingan kedua model menunjukkan bahwa model Lewis lebih sesuai untuk memprediksi laju pengeringan jamur tiram dibandingkan model Page. Hal ini sesuai dengan penelitian Ghaderi dkk. (2012) yang menyatakan bahwa model Lewis lebih sesuai dibandingkan model Page pada pengeringan jamur kancing dan digunakan pula pada penelitian Kulshreshtha dkk. (2009) tentang kualitas jamur setelah proses pengeringan.

\section{Perilaku Rehidrasi}

Rehidrasi dilakukan setelah proses pengeringan. Rehidrasi berhubungan dengan jumlah air yang mampu diserap oleh produk pangan kering pada periode waktu tertentu. Selama proses rehidrasi, bahan kering yang direndam dalam air atau media cair lainnya akan mengalami perubahan fisikokimia, seperti kadar air, porositas, volume, suhu, gelatinisasi dan tekstur. Rehidrasi meliputi beberapa proses yang terjadi secara paralel, termasuk penyerapan air ke dalam bahan kering, migrasi media cair melalui saluran berongga dan penyebaran melalui matriks solid, pembengkakan pada titik tertentu di matriks solid, dan pelarutan zat padat telarut oleh cairan ekternal (Marabi dan Saguy, 2009). Perilaku rehidrasi suatu produk dapat digambarkan oleh rasio rehidrasi. Hasil
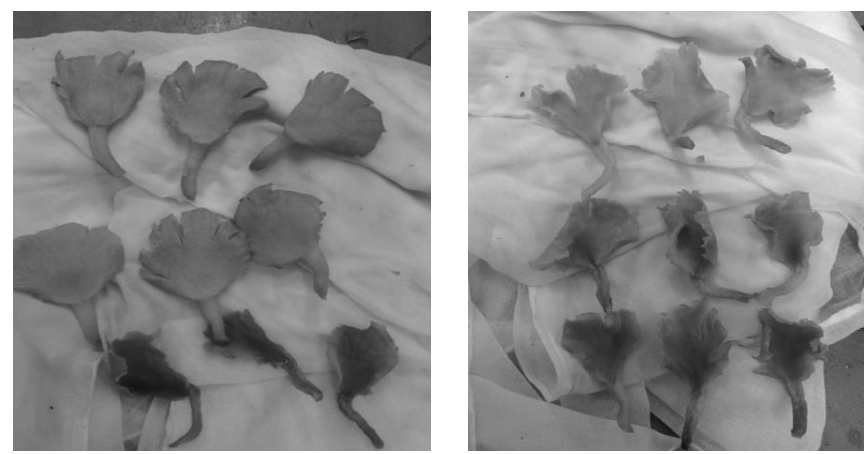

Gambar 6. Jamur tiram setelah direhidrasi. Atas ke bawah JS, JC, dan JB (kiri), JMa, JMb, dan JMc (kanan)

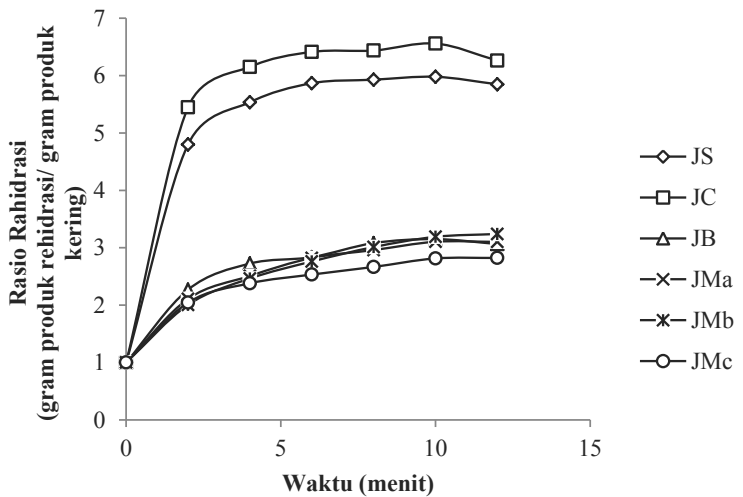

Gambar 7. Rasio rehidrasi sampel selama rehidrasi

rehidrasi jamur tiram kering disajikan pada Gambar 6.

Rasio rehidrasi merupakan perbandingan antara bobot produk pada waktu rehidrasi terhadap bobot keringnya. Rasio rehidrasi seluruh sampel yang diukur setiap 2 menit selama 12 menit dapat dilihat dalam Gambar 7. Rasio rehidrasi tertinggi dimiliki oleh sampel JC yang dapat mencapai 6,56, kemudian diikuti oleh sampel JS yang dapat mencapai 5,98, sedangkan sampel JMb, JMa, JB, dan JMb mencapai kisaran 2,82 hingga 3,24.

Perbedaan rasio rehidrasi antara sampel JS dan JC dengan sampel JB, JMa, JMb, dan JMc disebabkan oleh perbedaan pretreatment yang dilakukan. Sampel JB, JMa, JMb, dan $\mathrm{JMc}$ mendapatkan perlakuan blanching saat pretreatment, sedangkan sampel JS dan JC tidak mendapatkan perlakuan blanching. Selama proses blanching, udara dalam jaringan jamur tiram dikeluarkan dan terjadi pelipatan jaringan lamella pada jamur, sehingga antar jaringan jamur tiram akan lebih rapat (Vullioud dkk., 2011).

Blanching yang diharapkan dapat meningkatkan kualitas jamur tiram, terutama dari segi warna, tidak terlihat pengaruh yang nyata pada data di atas. Tidak terlihatnya efek pretreatment blanching dan penambahan natrium metabisulfit pada sampel dapat disebabkan karena tidak dilakukannya perusakan atau pelukaan terhadap jamur tiram, jamur tiram yang digunakan pada penelitian dipanen secara hati-hati dan dibiarkan utuh. Reaksi pencoklatan enzimatik sendiri terjadi ketika enzim penyebab pencoklatan, seperti polifenol oksidase (ppo) dan komponen fenolik, bereaksi ketika jaringan terbuka karena kerusakan (Quevedo dkk., 2011). Selain itu, jamur yang digunakan adalah jamur segar yang dipanen pada hari yang sama dengan hari penelitian, sehingga belum sempat terjadi reaksi pencoklatan yang biasanya dimulai sehari setelah pemanenan (Walde dkk., 2005). Quevedo dkk., (2016) menambahkan bahwa reaksi pencoklatan enzimatis pada jamur secara kritis terjadi pada suhu $96,6{ }^{\circ} \mathrm{C}$ berdasarkan metode Mean, sedangkan dengan metode Kinetik Fraktal terjadi pada suhu $40,3{ }^{\circ} \mathrm{C}$. 


\section{KESIMPULAN}

Model Lewis lebih sesuai untuk memprediksi laju pengeringan jamur tiram dibandingkan dengan model Page. Waktu yang dibutuhkan untuk mengeringkan sampel jamur tiram tanpa perlakuan dan jamur tiram dengan perlakuan pencucian tanpa blanching hingga mencapai kadar air 12\% adalah 150 menit, lebih cepat dibandingkan waktu yang dibutuhkan untuk mengeringkan sampel dengan perlakuan lainnya. Perilaku rehidrasi menunjukkan bahwa sampel jamur tiram tanpa perlakuan dan jamur tiram dengan perlakuan pencucian tanpa blanching, merupakan sampel terbaik yang memiliki rasio rehidrasi yang lebih tinggi dibandingkan sampel lainnya.

\section{DAFTAR PUSTAKA}

Alam, N., Amin, R., Khan, A., Ara, I., Shim, M.J., Lee, M.W. dan Lee, T.S. (2008). Nutritional analysis of cultivated mushroom in Bangladesh-Pleurotus ostreatus, Pleurotus sajor-caju, Pleurotus florida and Calocybe indica. The Korean Society of Mycology 36(4): 228-232.

Arora, S., Shivhare, U.S., Ahmed, J. dan Raghavan, G.S.V. (2011). Drying kinetics of Agaricus bisporus and Pleurotus florida mushroom. American Society of Agricultural Engineers 46(3): 721-724.

AOAC. (1995). Official Method of Analysis of the Association of Official Agricultural Chemist 16th Edition. AOAC International, Virginia.

Belloso, M.B. dan Fortuny, R.S. (2010). Advances in FreshCut Fruits and Vegetables Processing. Boca Raton: CRC Press.

Bhattacharya, M., Srivastav, P.P. dan Mishra, H.N. (2014). Optimization of microwave-convective drying of oyster mushrooms (Pleurotus ostreatus) using respose-surface methodology. International Food Research Journal 21(4): 1575-1581.

CODEX Alimentarius Commision (1981). Codex Standard for Dried Edible Fungi CODEX STAN 39-1981.

Doymaz, I. (2014). Drying kinetics and rehydration characteristics of convective hot-air dried white button mushroom slices. Journal of Chemistry. 2014:1-8. Doi: dx.doi.org/10.1155/2014/453175.

Erbay, Z. dan Icier, F. (2010). A review of thin layer drying of foods: theory, modeling, and experimental result. Critical Review in Food Science and Nutrition 50: 441464. Doi: 10.1080/10408390802437063.

FDA (Food and Drugs Administrations) (2013). Annex J: Summary of Current Food Standars. http://www.fda.
gov.ph/attachments/article/71149/Annex\%20J\%20 -\%20FOOD\%20STANDARDS.pdf. [2 Januari 2016].

Ghaderi, A., Abbasi, S., Motevali, A. dan Minaei, S. (2012). Comparison of mathematical models and atificial neural networks for prediction of drying kinetics of mushroom in microwave-vacuum drier. Chemical Industry and Chamical Engineering Quarterly 18(2): 283-293.

Giri, S.K. dan Prasad, S. (2007). Drying kinetics and rehydration characteristics of microwave-vacuum and convective hot-air dried mushrooms. Journal of Food Engineering 78 (2): 512-521. Doi:10.1016/j/ jfoodeng.2005.10.021.

Guiné, R.P.F. dan Barocca, M.J. (2011). Influence of freeze-drying treatment on the texture of mushrooms and onions. Croatia Journal of Food Science and Technology 3(2): 26-31.

Hassan, F.R.H. dan Medany, G.M. (2014). Effect of pretreatments and drying temperatures on the quality of dried Pleurotus mushroom spp. Egyptian Journal of Agricultural Research 92 (3): 1009-1023.

Jambrak, A.R., Mason T.J., Paniwnyk, L. dan Lelas, V. (2007). Accelerated drying of button mushrooms, Brussels sprouts and cauliflower by applying power ultrasound and its rehydration properties. Journal of Food Engineering 81: 88-97.

Kotwaliwale, N., Bakane, P. dan Verma, A. (2007). Changes in textural and optical properties of oyster mushroom during hot air drying. Journal of Food Engineering 78: 1207-1211.

Kulshreshtha, M., Singh, A. dan Deepti, V. (2009). Effect of drying conditions on mushroom quality. Journal of Engineering Science and Technology 4(1): 90-98.

Marabi, A. dan Saguy, I.S. 2009. Rehydration and reconstitution of food. Di dalam: Ratti C, editor. Advance in Food Dehydration. Boca Raton (US): CRC Press.

Patil, S.S., Ahmed, S.A., Telang, A.M. dan Baig, M.M.V. (2010). The nutritional value of pleurotus ostreatus (Jacq.: FR) kumm cultivated on different lignocellulostic agro-wastes. Innovative Romanian Food Biotechnology 7: 66-76.

Quevedo, R., Ronceros, B., Garcia, K., Lopez, P. dan Pedreschi, F. (2011). Enzymatic browning in sliced and pureed avocado: a fractal kinetic study. Journal of Food Engineering 105(2): 210-215.

Quevedo, R., Pedreschi, F., Bastias, J.M. dan Diaz, O. (2016). Correlation of the fractal enzymatic browning rate with 
the temperature in mushroom, pear, and apple Slices. LWT-Food Science and Technology 65: 406-413.

Vullioud, M.B., Rusalen, R. dan De Michelis, A. (2011). Blanching process of oyster mushrooms (Pleurotus ostreatus) and its effects on parameters of technological interest in Argentina. Micologia Aplicada International 23 (2): 47-53.
Walde, S.G., Velu, V., Jyothirmayi, T. dan Math, R.G. (2006). Effects of pretreatment and drying methods on dehydration of mushroom. Journal of Food Engineering 74: 108-115. 